\title{
Residential suburbanisation in the hinterland of Bratislava - a case study of municipalities in the Austrian border area
}

\author{
Renáta FARKAS ${ }^{1}$ and Michal KLOBUČNíK ${ }^{1}$
}

\begin{abstract}
This paper provides an overview of the process of residential suburbanisation in the hinterland of Bratislava. The study focuses on the municipalities around the Austrian border area. The main aim of the paper is to investigate the characteristics of cross-border suburbanisation, which is a significant spatial phenomenon in the municipalities of northern Burgenland and the south-eastern part of Lower Austria. The analysis has a spatio-temporal dimension, as it depicts the time-space characteristics of the phenomenon - both for a single time point, as well as for a time series from the approximate beginning of the onset of suburbanisation up to the present. While monitoring the growth of the number of Slovaks in the study area, we observed a gradual increase in all the selected municipalities of the Austrian border area, with the distance from Bratislava being a significant factor here. The analysis of migration in the surveyed municipalities showed predominantly positive migration efficiency - immigration was negated by emigration only to a small extent (compared to suburbanisation in the Slovak hinterland of Bratislava, which is, however, relatively high). The structural characteristics of Slovak immigrants, where the younger age group of 30 to 44 years followed by a child component up to 14 years predominated, attest to the ongoing process of suburbanisation. The research confirmed the advancing residential suburbanisation and expansion of the cross-border suburban hinterland of Bratislava.
\end{abstract}

Keywords: residential suburbanisation, cross-border mobility, migration, Bratislava, Austrian border area, Slovaks in the Austrian border area

Received August 2021, accepted October 2021

\section{Introduction}

The following paper is a case study of municipalities in the Austrian border area from the aspect of the process of residential suburbanisation in the hinterland of Bratislava. During the 1980s and 1990s, when the process of residential suburbanisation in the hinterland of Vienna had already reached its peak, socialist urbanisation was gradually subsiding in Bratislava (Matznetter, W. 2004). The fall of socialism in Slovakia in 1989, including the subsequent transformation of society and the economy related to this also resulted in a change in the predominant urbanisation processes of the state.

In the newly founded Slovak Republic, conditions for the wider development of subur- banisation had not yet been created (ŠveDA, M. 2011a; ŠvedA, M. and KRIŽAN, F. 2011). The construction industry had fallen into a deep recession; financial support mechanisms from both the state and the banking sector (e.g. mortgages) for the development of housing construction were lacking. However, after the resolution of this shortcoming, residential suburbanisation gradually began to develop in our country, which had only begun to show its first signs in the 1990s. And so, residential suburbanisation in the hinterland of Bratislava took on an imaginative dimension after the turn of the new millennium, which had been characterised by the construction of new houses and residential sites on so-called "green-fields", as well as the transfer of the urban population and

\footnotetext{
${ }^{1}$ Department of Economic and Social Geography, Demography and Territorial Development, Faculty of Natural Sciences, Comenius University, Ilkovičova 6, 842 15, Bratislava 4. Slovakia. E-mails: renata.farkas@uniba.sk, michal.klobucnik@uniba.sk
} 
its activities to the surrounding municipalities of the Bratislava hinterland (ŠvedA, M. 2011a).

However, cross-border suburbanisation is a specific and more complicated form of residential suburbanisation. Its origin and development require that more conditions be fulfilled since it goes beyond state, cultural, and linguistic borders. For this reason, it is understandable that suburbanisation only began to develop in Slovakia after a delay of several years when compared to "common" residential suburbanisation. In the case of Bratislava, Slovakia's accession to the European Union in 2004 and the Schengen Area in 2007 were widely accepted as the starting mechanisms of this process (IrA, V. et al. 2011; BALIzs, D. and BAjмóczy, P. 2018, 2019). The reason was that the two events led to the formation of an integrated border between the Slovak Republic and the Republic of Austria. The unrestricted movement of people, goods, and capital across the national border was thus ensured.

This paper provides an in-depth analysis of Austrian border area municipalities, which fall into the suburban hinterland of Bratislava within three Austrian districts - Gänserndorf, Bruck an der Leitha, Neusiedl am See - all of which directly border Bratislava itself. The ongoing cross-border suburbanisation in this area has a significant time-space dimension. We assume that the intensity of the process has changed markedly over time, with Slovaks contributing to a large extent in this process. We also believe that the distance of suburban Austrian municipalities from Bratislava plays a significant role as well. Migration flows of Slovak citizens to suburban municipalities as well as their age structure are further aspects that complete the picture of the ongoing process of crossborder suburbanisation.

\section{Theoretical background}

There is no uniformly recognised and defined time for the onset of decentralisation tendencies of population distribution in the USA and Western Europe. Some authors tend to date the beginning of modern suburbanisation from either 1815 (JACKsON, K.T. 1987) or 1920 (РтÁčEK, P. 2002). In the case of Austria, suburbanisation reached its highest intensity in the $20^{\text {th }}$ century (Matznetter, W. 2004). However, the development of cross-border settlement of the countries of post-communist Central and Eastern Europe has been different, since the suburbanisation processes only began after the fall of the communist regime and were accompanied by a considerable delay (Stanilov, K. and SýKora, L. 2014).

Residential suburbanisation is a process that has significantly transformed the social and physical environment of the Bratislava hinterland from rural to suburban in the last two decades. It has affected the spatial structure of settlements (ŠvedA, M. 2011a; ŠvedA, M. and PAzúr, R. 2018) and the social and demographic structure of the population (ŠvEDA, M. and ŠUŠKA, P. 2014). Further, it has caused significant changes in land use (ŠvEDA, M. and VigAšová, D. 2010; ŠvedA, M. 2011b).

The term 'residential suburbanisation' is most often understood as the shift of residents, households, and their activities outside the territory of urban centres, usually to their hinterland with a low population density (РтÁčEK, P. 2002). This is expressed most notably by the construction of new family houses on agricultural land. In addition, residential suburbanisation in these geographical conditions is characterised by increasing residential densities or renovation of the original housing stock (ŠvedA, M. 2011a). The spatial extent of suburbanisation mostly depends on the population size of the city (KubEš, J. and NovÁčEK, A. 2019).

As an analogy, it can be said that cross-border residential suburbanisation is a process in which the migration of the urban population and their activities to the adjacent rural area on the opposite side of the border is monitored. Since suburbanisation can be divided into both residential and commercial categories (or in some cases seasonal), it is necessary to state that in this article the term 'cross-border suburbanisation' shall be understood exclusively in its residential form. 
The phenomenon of cross-border suburbanisation has been observed in several places in the geographical area of Europe. Examples are known from the German-Netherlands (Strüver, A. 2005), Italian-Slovenian (JAGodic, D. 2011) and German-Polish borders (Barthel, M. and Barthel, E. 2018).

Cross-border suburbanisation in the hinterland of Bratislava represents a rare type of suburbanisation due to the human geographic location of the capital situated on the border of three states. Initially, its development was captured by a few authors who defined the first suburbanised municipalities beyond the Slovak borders (DILLINGER, T. 2004; Slavík, V. et al. 2011; Šveda, M. 2011a). On the Austrian side of the border, they labelled three municipalities (Kittsee, Berg, Wolfsthal) as cross-border-suburban. Several years later, these Austrian border municipalities in the suburban hinterland of Bratislava were described by Huemer, J. (2018) as the most dynamically growing villages in Austria.

It can generally be stated that the development of cross-border suburbanisation in the hinterland of Bratislava is not only the result of the classical development of suburbanisation, which progressed in conformity with the evolutionary development of the urban organism or the urban region, but is also a specific result, since its realisation required the interplay of several positive circumstances.

As previously mentioned, the first catalyst for the development of cross-border suburbanisation occurred with the Slovak Republic's accession to the European Union in 2004, and the second with its inclusion in the Schengen area in 2007. Both events significantly contributed to the increased mobility of people in cross-border areas and opened the door to new opportunities, including suburbanisation.

According to Decoville, A. and Durand, F. (2018), cross-border population flows are driven by differences between the two sides of the state border, whether in commodity prices, wages, unemployment rates, or real estate prices. In the case of the cross-border suburbanisation studied in this paper, the significant "pull" effects of decentralisation of the population included better transport accessibility and lower real estate prices (HARdi, T. et al. 2010; Slavík, V. et al. 2011; ŠvedA, M. 2011a; Huemer, J. 2018).

Nowadays, however, due to the cross-border mobility and migration of the population, the agglomeration of the city of Bratislava extends over the state borders of Austria and Hungary (HARDi, T. 2016). Overall, this is an area which, according to HARDI, T. (2016), is inhabited by a specific group of transnational borderlanders, whose cross-border way of life is not motivated by ethnic or linguistic reasons, but rather by the practicality of everyday life. According to Martinez, O.J. (1994), transnational borderlanders are people who maintain significant ties with a neighbouring nation. They are individuals whose lifestyle strongly reflects foreign influences.

\section{Methodology}

We obtained the data for the research from the sources of the Austrian Statistical Office (Statistik Austria) from the STATcube database - Statistical Database. The analytical part was commenced by applying an indicator concerning the share of Slovaks to a wider range of municipalities in the three border districts of Gänserndorf, Bruck an der Leitha, and Neusiedl am See - with a total of 104 municipalities (Figure 1). Then, based on an analysis of the number of Slovaks in the border area, we narrowed down the number of municipalities which can be considered subject to cross-border suburbanisation (Figure 2).

In the investigated areas, we identified 17 municipalities where the relative share of Slovaks exceeded 5 percent of the municipal population, and it was these municipalities that formed the narrower selection of municipalities as subject of more detailed research. The reason for choosing the above indicator for creating a smaller coverage of municipalities was our fundamental premise that it is not possible to label those Austrian municipalities in the hinterland of Bratislava as suburban that do not have a Slovak popu- 
Share of Slovaks (\%)

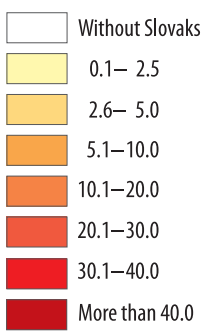
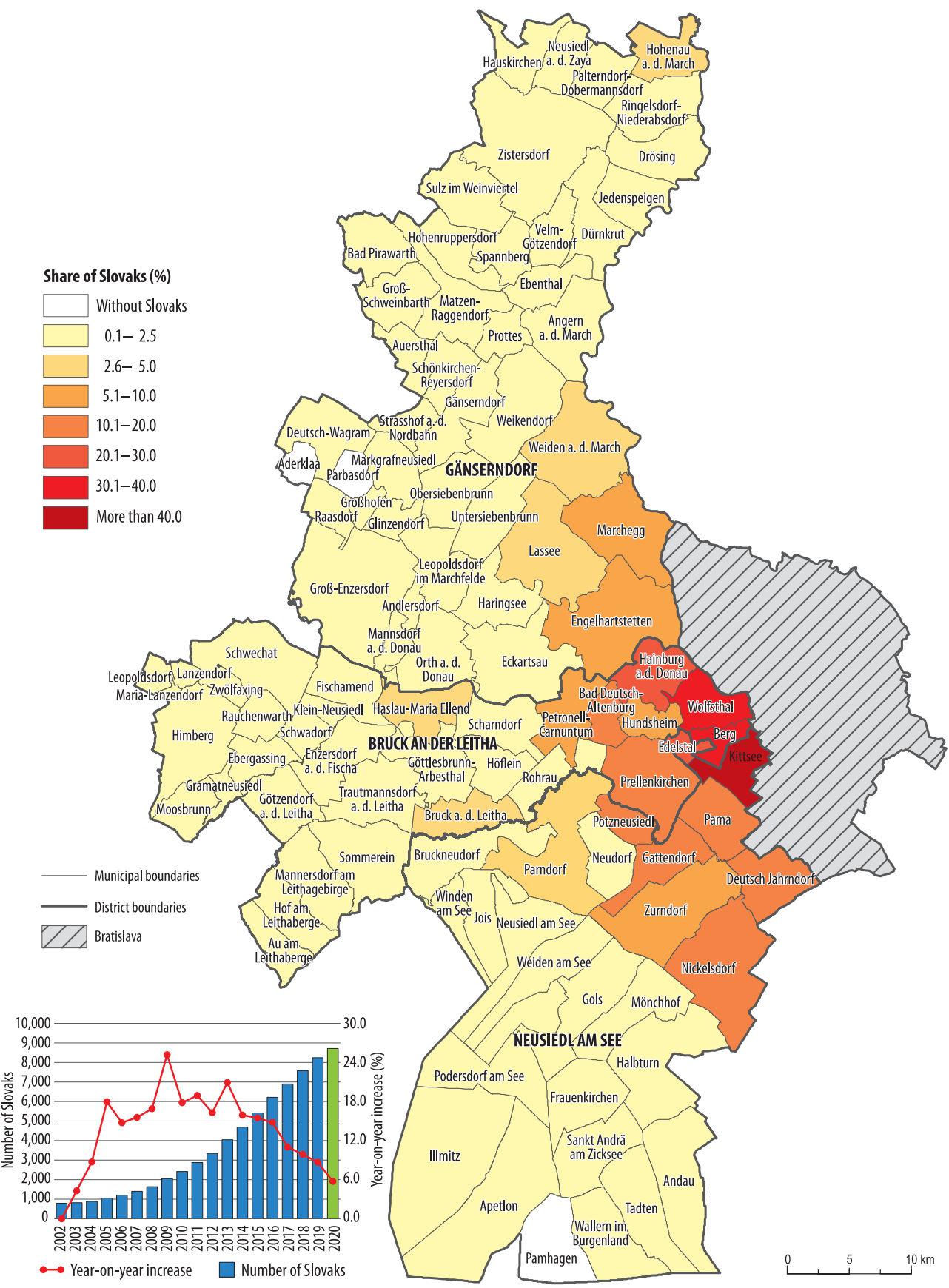

Fig. 1. Relative representation of Slovaks in the municipalities of the districts of Gänserndorf, Bruck an der Leitha, and Neusiedl am See (2020). Source: STATcube - Statistical Database (https://www.statistik.at). Processed by the authors. 

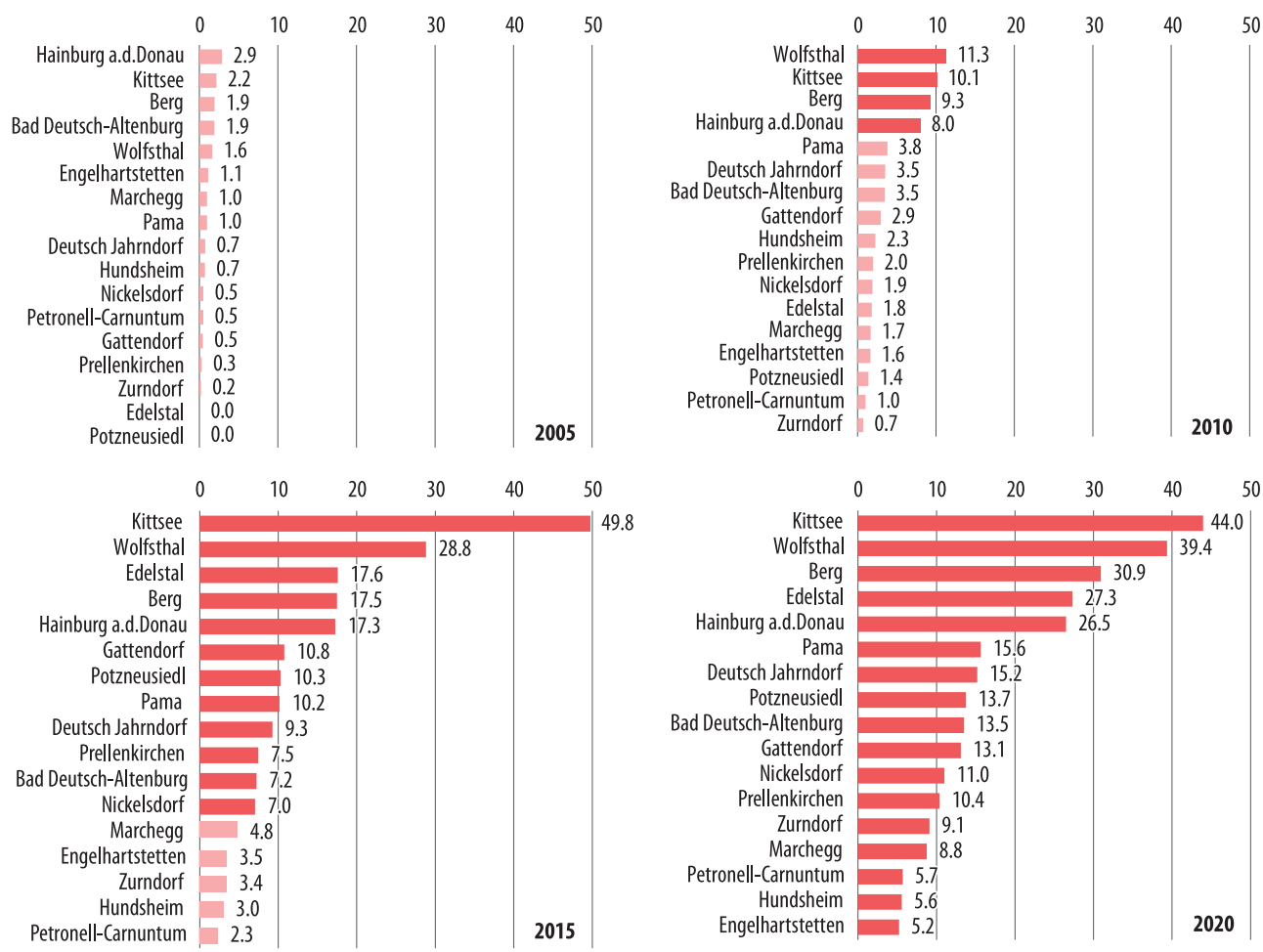

Fig. 2. Relative representation of Slovaks (in \%) in selected municipalities of the Austrian border area in the hinterland of Bratislava (2005, 2010, 2015 and 2020). Source: STATcube - Statistical Database (https://www. statistik.at). Processed by the authors.

lation. We also had to consider the fact that these three Austrian districts have the phenomenon of double suburbanisation (i.e. from Bratislava and Vienna) (Meyfroidt, A. 2017), and the relative share of Slovaks represented an indicator by which we could define the suburbanising influence of Bratislava.

The migration of the urban population to suburban localities is a crucial aspect of suburbanisation (Š́rochA, B. et al. 2017). In the scope of the research, we also analysed the migration of residents of the affected municipalities, and in order to do so, we focused on migration efficiency (migration efficiency ratio - MER). This relationship applies (Stillwell, J. et al. 2000):

$$
\operatorname{MER}_{i}=\frac{D_{i}-O_{i}}{D_{i}+O_{i}} * 100,
$$

where $M E R_{i}=$ migration efficiency ratio of the municipality $i, D_{i}=$ the sum of immigrants (inflows) to the municipality $i$ from other municipalities, $O_{i}=$ the sum of emigrants (outflows) from the municipality $i$ to other municipalities.

The values range from -100 to +100 . With a value of 0 , the migration efficiency is zero, which means that there has been no change in population, although both immigration and emigration have taken place. The closer the value of migration efficiency is to the value of +100 , the greater the positive migration efficiency (immigration is not "negated" by emigration, or only minimally). In contrast, in the case of values approaching the value of -100 , those emigrating are not replaced by those immigrating, or only to a very low extent. Migration efficiency basically measures the 
degree of imbalance or asymmetry between a pair of migration flows. If flows are symmetrical, they suggest that migration functions as a process that keeps the settlement system in dynamic balance (Rowland, D.T. 1978).

\section{Results}

The development of the number of Slovaks in our case represents the significant determinant of the research, which is considered to be an essential prerequisite for demonstrating the cross-border suburbanisation of the Bratislava hinterland. The representation of Slovaks in the population structure of the municipalities of the Austrian border area is a valuable indicator of residential suburbanisation showing the degree of decentralisation processes from Bratislava to its cross-border suburban hinterland. With that said, it is no different in the case of the Hungarian hinterland of Bratislava, where the authors BALIzs, D. and BAjмóczy, P. (2019) indicated an increase in the number of Slovaks in the villages of Rajka, Bezenye, and Dunakiliti, as well as others.

According to Šveda, M. et al. (2020a), Bratislava, as the dominant residential centre, creates a network of various connections, where the intensity decreases with increasing distance from its core. Figure 1 depicts the relative share of Slovaks in the total population of the municipalities of the three Austrian districts that neighbour Bratislava. As we can see, the largest share of the Slovak population is in the municipalities closest to Bratislava. We can also observe a gradual decline in the relative number of Slovaks with increasing distance from the Slovak capital, as well as the relatively compact nature of the cross-border region with the representation of the Slovak minority. However, as far as this region is concerned, it is interesting to note that the relative share of Slovaks is higher in its southern part than in the northern part. Outside the mentioned region of the 17 selected municipalities, the share of Slovaks in the districts of Neusiedl am See, Bruck an der Leitha, and Gänserndorf is marginal. We con- sider the rising number of Slovaks and their increasing share in the population of Austrian municipalities as the essential characteristic of residential suburbanisation. It distinguishes the suburbanisation of Bratislava from the suburbanisation of Vienna. Therefore, we exclude from our research municipalities that have a very low share of Slovaks in the total population of the municipality. For this distinction, we set the lower limit at a level of 5 percent Slovak population in the total population in the given year 2020 .

In the set of graphs provided (see Figure 2 ), we can see the development of growth in the number of Slovaks in the selected municipalities of the Austrian border area in 5-year intervals. In summary, it is evident that for the monitored 15 years, significant changes occurred in the relative representation of Slovaks in the total population of the selected municipalities, with the largest growth occurring in 2015 and 2020. While in 2005 no selected municipality had a share of Slovaks over 5 percent, in 2010, Wolfsthal, Kittsee, Berg, and Hainburg an der Donau significantly dominated. The significant rise in the number of Slovaks in the total population of these municipalities is the result of their initial suburbanisation in the hinterland of Bratislava after the Slovak Republic's accession to the European Union and the Schengen Area (IRA, V. et al. 2011; Balizs, D. and BAjмóczy, P. 2018, 2019). Furthermore, the excellent transport accessibility to the centre of Bratislava combined with favourable property prices was a crucial criterion for their specific choice (HARd, T. et al. 2010; Slavík, V. et al. 2011; ŠvedA, M. 2011a; Huemer, J. 2018).

In 2015, 12 municipalities had already reached more than a 5 percent share of Slovak residents. For example, in Kittsee, the relative share of Slovaks soared from 11.3 percent (2010) to a record 49.8 percent (2015). From a spatial point of view, in 2015 , the number of municipalities directly neighbouring Bratislava was still growing, (e.g. Pama or Deutsch Jahrndorf). However, in this period, the Slovak population began to move more notably to municipalities that were not 
immediately adjacent to Bratislava (Edelstal, Nickelsdorf, Gattendorf, Potzneusiedl, and Prellenkirchen). We consider the year 2020 to be evidence of the continuing suburbanisation of the hinterland of Bratislava, when the share of Slovaks in the above-mentioned municipalities continued to grow; while in four other municipalities the relative representation of Slovaks rose above the 5 percent threshold (Marchegg, Petronell-Carnuntum, Hundsheim, Engelharstetten). In Kittsee, the share slightly decreased compared to 2015, and according to the relative representation of Slovaks, the village of Wolfsthal came significantly closer to it.

Figure 3 shows the dynamics of the development of growth/decline of the population of the affected municipalities. When looking at the three consecutive periods, the number of inhabitants in the given municipalities developed differently. The majority of the analysed municipalities maintained the trend of population growth in all periods. Of all the municipalities, the most extreme population growth was seen in the mu- nicipality directly neighbouring Bratislava, namely Kittsee, which increased by 75.5 percent from the start of the analysed period (2006-2020). According to ŠveDA, M. et al. (2020b), since 2005, the number of inhabitants has increased tenfold in the municipality by migration each year; in the last decade alone, migration reached 150 inhabitants per year. More than 70 percent of this increase was accounted for by cross-border migration. As part of our research, we found that the most dynamic period can be considered the years 2011-2015 when the municipality increased its population by almost 40 percent. We also recorded high growth in population during the three periods in another border municipality: Wolfsthal (from the beginning of the analysed period, the village grew by $55.9 \%)$; in Berg, the number of inhabitants increased by 32.5 percent over 15 years, and in Edelstal by 29.6 percent. Constant modest growth of inhabitants during the three periods occurred, for example, in the town of Hainburg an der Donau or in neighbouring Bad Deutsch-Altenburg.

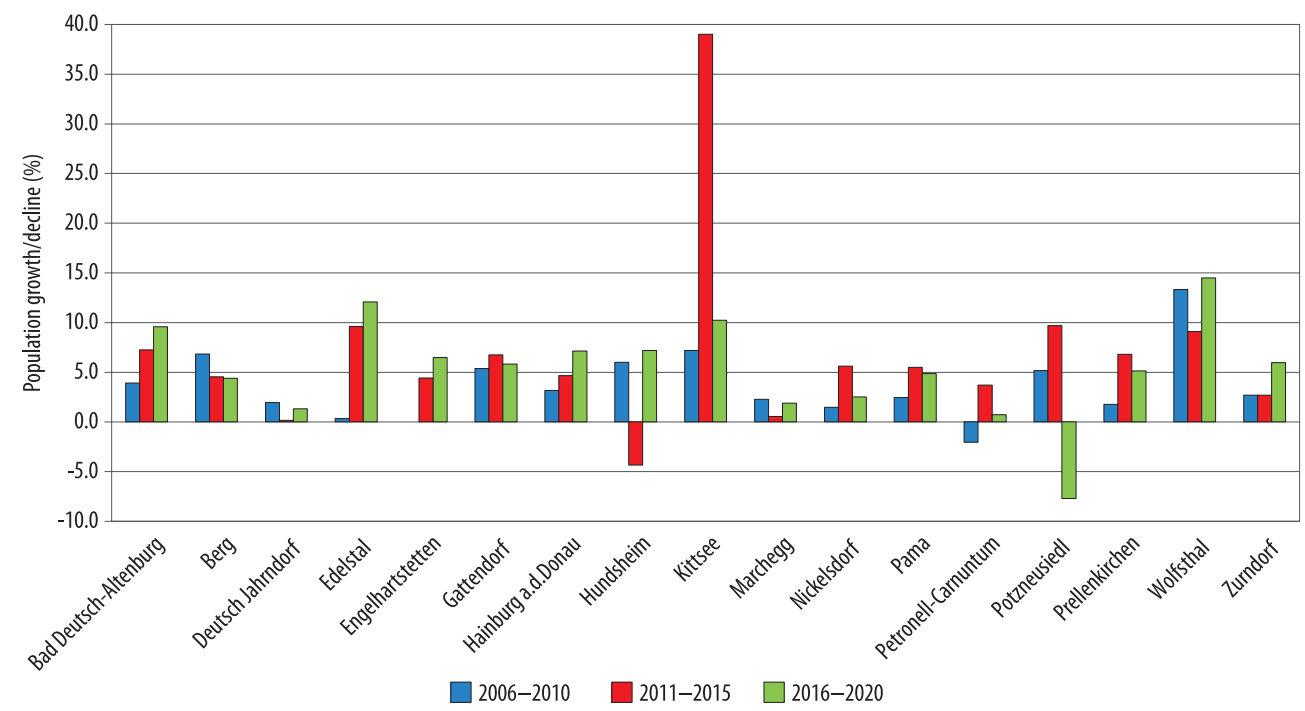

Fig. 3. Growth/decline of inhabitants (in \%) of selected municipalities of the Austrian border in the hinterland of Bratislava (2006-2010, 2011-2015, 2016-2020). Source: STATcube - Statistical Database (https://www.statistik. at). Processed by the authors. 
Migration, which is defined as a dynamic and constantly modifying process that causes changes in the socio-geographical, economic, social, and demographic structures of areas, represents a natural component of people's lives (KáčErová, M. and Horváthová, R. 2014). Citizens of the Slovak Republic, in accordance with European Union legislation on the free movement of EU citizens, have the right to stay in Austria for more than three months. Afterwards, if they come to Austria with the intention of permanent or temporary settlement, they are obligated to register with the competent public authority within four months from the date of arrival, where they will obtain an "Aufenthaltskarte" residence permit upon request. After five years of legal and continuous residency in Austria, they acquire the right to obtain permanent residence. Upon request, they are issued a certificate of permanent residence, the so-called "Bescheinigung des Daueraufenthalts" ("Certificate of permanent residence") (www.oesterreich.gv.at).

The migration efficiency of Slovaks (Figure 4) showed positive values in all the analysed municipalities of the Austrian border area; this means that in the examined 5 -year periods, immigration (immigrants) exceeded emigration (emigrants). It is clear, however, that in some municipalities, migration efficiency has slightly weakened over the periods (e.g. Gattendorf, Nickelsdorf, Pama, Wolfsthal or Zurndorf), while in others, it has slightly strengthened (e.g. Bad DeutschAltenburg, Engelhartstetten) or remained at about the same level (Hainburg an der Donau, Marchegg).

Since 2008, we have witnessed a relatively sudden upswing in the number of immigrating Slovaks. The increase can be explained by the entry of Slovakia into the Schengen Area, which removed the barrier to free movement of Slovak citizens entering Austria. The rapid rise of Slovak immigrants in the surveyed municipalities of the Austrian border area peaked for the first time in 2012 when their number reached 670 . Since that year, the number of immigrants has ranged from 600 to 700 people per year. We recorded the highest number of immigrants in 2016 - a total of 676 persons. From the viewpoint of the emigration of Slovaks, we perceive a gradual increase in their number since 2010 with a maximum value in 2019, when 284 Slovaks left selected municipalities in the Austrian border area (https://www.statistik.at). We can also

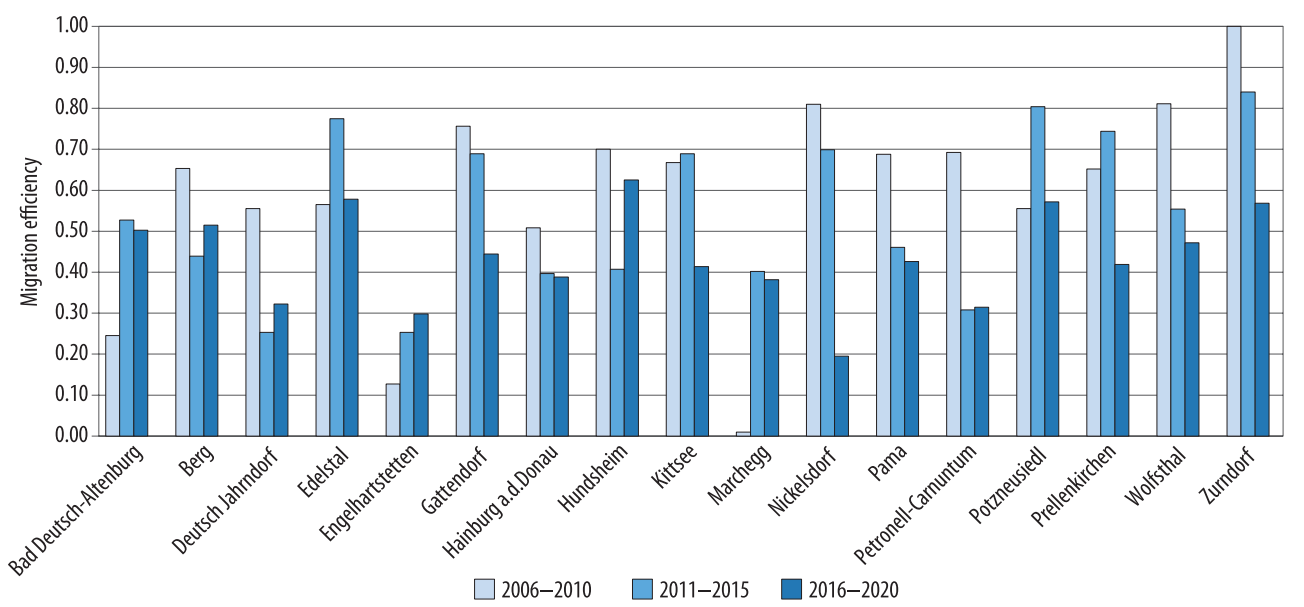

Fig. 4. Migration efficiency in selected municipalities of the Austrian border area in the hinterland of Bratislava (2006-2010, 2011-2015, 2016-2020). Source: STATcube - Statistical Database (https://www.statistik.at). Processed by the authors. 
perceive the issue of residential stability as a certain compacted result of the evaluation of the ideas and expectations of the population concerning the new environment and its social and material characteristics. The desire to stay in the locality for a longer period can be an important signal, which not only testifies to satisfaction with the quality of housing but can also be an indicator of the integration of new residents into local social structures. On the contrary, the desire to make a change of residence may be a reflection of the nonfulfilment of the original expectations about better housing (ŠvedA, M. 2016).

Within each of the analysed 5-year periods, the town of Hainburg an der Donau and the municipalities of Kittsee and Wolfsthal showed the largest migration turnover (immigrants + emigrants). Wolfsthal and Hainburg an der Donau have experienced a relatively high level of irregular migration efficiency over 15 years, falling slightly since its peak in 2008 (even with some fluctuations). We observed a similar trend in the municipality of Kittsee as well, which reached its maximum migration efficiency in 2011 (Figure 5).

In terms of the available structural characteristics of migrants, we charted the representation of individual age groups in the total number of immigrants (Figure 6), since migration has a significant effect on changes in the population structure and reproductive behaviour of the population (PoDolák, P. and ŠvedA, M. 2019). As we can observe, the 30 to 44 years old group significantly predominates among immigrants, followed by the children's component up to 14 years old. Seniors and people over the age of 60 are relatively absent in the population of Slovak immigrants in selected Austrian municipalities. The presented findings correlate with the general starting points of suburbanisation, which emphasise the significant representation of young couples and families with small children in suburbanisation (OuŘEDNíčEK, M. 2002), as well as with specific migration characteristics of the Slovak hinterland of Bratislava (Podolák, P. and ŠvedA, M. 2019).

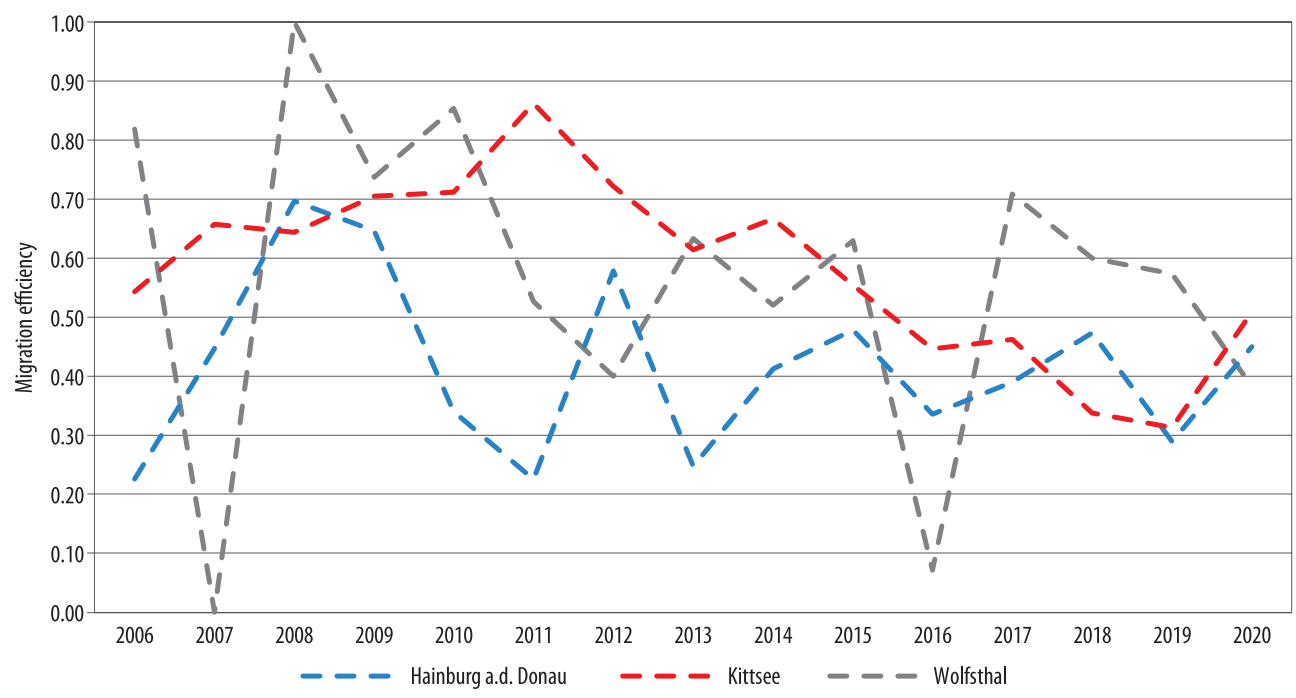

Fig. 5. Migration efficiency in selected municipalities of the Austrian border area in the hinterland of Bratislava (Hainburg an der Donau, Kittsee and Wolfsthal) in the years 2006-2020. Source: STATcube - Statistical Database (https://www.statistik.at). Processed by the authors. 


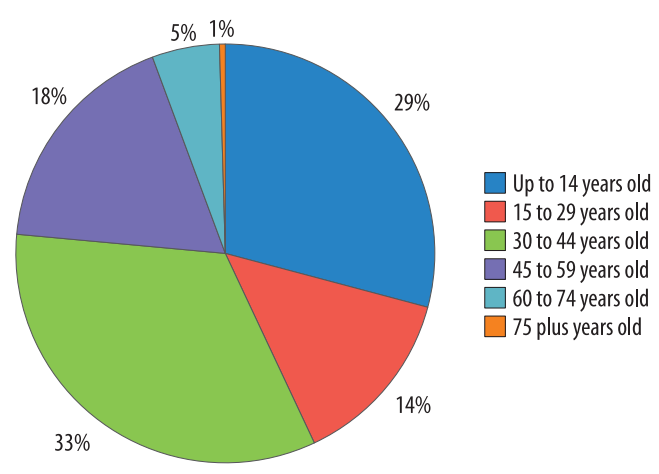

Fig. 6. Age structure of immigrating Slovaks to selected municipalities of the Austrian border area in the hinterland of Bratislava (2006-2020). Source: STATcube - Statistical Database (https://www.statistik.at). Processed by the authors.

\section{Conclusions}

Bratislava, together with its hinterland, represents an urban region with exceptionally large potential for further development. In 1993, it became the capital of the newly formed Slovak Republic, and its importance was further enhanced by Slovakia's entry into the European Union (2004) and the Schengen Area (2007). Important aspects of Bratislava's macro-location that have influenced the city's formation, historical development, and current development include a strategic location at the point of contact of two great cultures, a location between the cities of Vienna and Budapest, a gateway between the former western (capitalist) and the eastern (communist) world, as well as an important location in respect of other areas of Slovakia (KoRec, P. 2013). The presence of the state border with Austria and Hungary should be considered the most important aspect when assessing the microlocation (Korec, P. et al. 2020). At the origin and development of the process of cross-border suburbanisation, the specific political and geographical location of the city concerning the state borders of neighbouring countries is important (free movement of population and capital across state borders must be observed).
The position of Bratislava as a dynamic economic, administrative, political, and cultural centre was also connected with the gradual revival of (not only residential) construction. For this reason, there has been a significant increase in real estate and land prices in the city and its Slovak hinterland, as well as a significant increase in the possibilities for further development. Therefore, the Austrian border, with its several accessible municipalities in this area represents an attractive alternative for Bratislava residents considering suburban housing (IRA, V. et al. 2011).

When monitoring the development of the number of Slovaks, a gradually increasing number in all the selected municipalities of the Austrian border area was observed. In 2020, the municipalities of Kittsee, Wolfsthal, and Berg had the highest percentage of Slovak inhabitants, while in absolute terms, the most Slovaks lived in the town of Hainburg an der Donau. Therefore, we consider Kittsee, Wolfsthal, Berg, and Edelstal to be the most dynamically growing municipalities.

Within the surveyed municipalities in the hinterland of Bratislava, positive migration efficiency was manifested throughout the 2006-2020 period, that is, the number of arriving Slovaks (immigrants) showed higher values than departing Slovaks (emigrants). Immigrants heading to the Austrian hinterland of Bratislava are characterised by a greater emphasis on the quality of housing (for example, migrants heading to Rajka in Hungary, who are seeking more affordable housing). This quality is represented not only by the aesthetic environment of the "clean and tidy" municipalities of Austria, but also by the provision of services (for example, the availability of school facilities) (ŠvedA, M. et al. 2020b). However, life in Austria is often associated with other additional benefits that may persuade people to move there. In addition to a more favourable traffic situation, more advantageous mortgages or state housing allowances are offered. Often emphasised non-economic factors include higher environmental awareness, better services, and a higher level of office work, community spirit, and other positively per- 
ceived characteristics of social and cultural life (IRA, V. et al. 2011). Developers specialise in the new local market and build specifically for Slovak clients (Meyfroidt, A. 2016).

Migration in the functional metropolitan region of Bratislava is quite heterogeneous internally, thus migration trends are different between various categories of migrants that are separated by age and education. The Bratislava region attracts the youngest educated migrants (Novotný, L. and Pregi, L. 2019). The continuing process of suburbanisation, however, was also evidenced by structural characteristics, namely the age composition of Slovak immigrants, which was dominated by the age group of 30 to 44 years old, followed by a child component up to 14 years old.

One important topic that enters this issue is the coexistence of Austrians and Slovaks on the border. The results of research on the image of Slovakia and Austria pointed to clear differences in the perception of each neighbour and suggested that the many years of historical, geographical, and cultural affinity of the Austrian and Slovak populations may not yet mean mutual acceptance and cooperation (Kollár, D. 2001). Based on the study of Decoville, A. and Durand, F. (2018), the reason may be that the memory of the Iron Curtain will remains in the minds of people living on both sides of the state border for a long time.

The processes of urban expansion originating from the capital Bratislava will probably continue toward the interior of northern Burgenland (or Lower Austria). It can be assumed that interest in life in these regions will continue to grow. It is therefore necessary to find a way to reconcile the economic development of industrial sites and shopping centres with the residential construction of traditional structures which create an identity in the rural areas of the regions. The question is whether the existing tools (spatial planning, development plans, urban renewal) are sufficiently effective, and whether control measures or activities can continue to support the structural, economic, social, and cultural identity of peripheral zones (Kapeller, V. 2015).
Residential suburbanisation and the expansion of the cross-border suburban hinterland of Bratislava can be scientifically examined in the future through other indicators that are closely related to the suburbanisation process itself, such as research on housing construction in municipalities, analysis of transport accessibility, real estate prices, community behaviour and so on.

Acknowledgement: This contribution was undertaken as a part of the research project VEGA project No. 1/0278/20 Relationship of legitimacy, governance and public finances at the local level in the geographical perspective of Slovakia. This paper has undergone a professional linguistic correction by a lecturer Michael Jerry SABO.

\section{REFERENCES}

BALIzs, D. and Bajmóczy, P. 2018. Rajka: The "Hungarian suburb" of Bratislava. Space and Society 32. 54-75.

Balizs, D. and Bajmóczy, P. 2019. Cross-border suburbanisation around Bratislava: Changing social, ethnic and architectural character of the "Hungarian suburb" of the Slovak capital. Geografický časopis 71. (1): 73-98.

BARTHEL, M. and BARTHEL, E. 2018. Exploring Subbordia - the impact of suburbanisation in cross-border metropolitan regions. The case study of Szczecin and its German hinterland. Urban Development Issues 60. (1): 5-13.

Decoville, A. and DuRand, F. 2018. Exploring cross-border integration in Europe: How do populations cross borders and perceive their neighbours?. European Urban and Regional Studies 26. (2): 134-157.

Dillinger, T. 2004. Facing suburbanisation in the area of Bratislava, The border between Austria and the Slovak Republic. Urbani Izziv 15. (2): 121-124.

HARDI, T. 2016. Asymmetries in the formation of the transnational borderland in the Slovak-Hungarian border region. In European Borderlands: Living with Barriers and Bridges. Eds.: Boesen, E. and Schnuer, G., New York, Routledge, 176-192.

Hardi, T., Lados, M. and Tóth, K. (eds.) 2010. Magyarszlovák agglomeráció Pozsony környékén / Mad’arskoslovenská Aglomerácia v okolí Bratislavy (HungarianSlovak agglomeration in the surroundings of Bratislava). MTA Regionális Kutatások Központja, Nyugat-magyarországi Tudományos Intézet, Fórum Kisebbségkutató Intézet, Győr-Somorja, Stredisko regionálnych výskumov Mad’arskej akadémie vied, Západomad’arský vedecký inštitút, Fórum inštitút pre výskum menšín, Raab-Samorin. 
Huemer, J. 2018. Achtung Staatsgrenze! Die Suburbanisierung von Bratislava kennt keine Grenzen! In Grenzen: Theoretische, konzeptionelle und praxisbezogene Fragestellungen zu Grenzen und deren Überschreitungen. Hrsg.: Heintel, M., Musil, R. and Weixlbaumer, N., Wiesbaden, Springer.

IRA, V., Szöllös, J. and ŠUšKa, P. 2011. Vplyvy suburbanizácie v rakúskom a mad’arskom zázemí Bratislavy (Impacts of suburbanization in the Austrian and Hungarian hinterlands of Bratislava city). In Časovopriestorové aspekty regionálnych štruktúr ČR a SR. Eds.: AndrašKo, I., IRA,V. and Kallabová, E., Bratislava, Geografický ústav SAV, 43-50.

JACKSON, K.T. 1987. Crabgrass Frontier: The Suburbanization of the United States. Oxford, Oxford University Press.

JAGodic, D. 2011. Cross-border residential mobility in the context of the European Union: the case of the Italian-Slovenian border. Journal of Ethnic Studies 65. September, 60-87.

KÁČERovÁ, M. and Horváthová, R. 2014. Zahraničná migrácia Slovenska - demografické a priestorové aspekty (International migration of Slovakia - demographic and spatial aspects). Slovenská štatistika a demografia 24. (2): 33-51.

KAPELLER, V. 2015. Bevölkerungs- und Siedlungsdynamik im Grenzgebiet Nordburgenland und Bratislava. In Aktuelle und zukünftige Wohnbauentwicklung im Grenzgebiet Nordburgenland und Bratislava. Hrsg.: Kapeller, V. und Huemer, J., Wien, Institut für Stadtund Regionalforschung der ÖAW, 23-35.

Kollár, D. 2001. Obraz Rakúska a Slovenska u obyvatel'ov slovensko-rakúskeho pohraničia (Image of Austria and Slovakia viewed by the inhabitants of the Slovak-Austrian boundary area). Geografický časopis 53. (1): 59-74.

Korec, P. 2013. Poloha mesta Bratislava (The location of Bratislava). In Moderná humánna geografia mesta Bratislava: priestorové štruktúry,siete a procesy. Eds.: Bučé, J. and Korec, P., Bratislava, Univerzita Komenského, 7-25.

KoRec, P., ONDoš, S. and BAčík, V. 2020. Bratislava, od histórie cez socialistické mesto ku kapitalistickému mestu (Bratislava, from history during socialist city to capitalist one). Acta Geographica Universitatis Comenianae 64. (2): 195-228.

Kubeš, J. and NováčeK, A. 2019. Suburbs around the Czech provincial city of České Budějovice - territorial arrangement and problems. Hungarian Geographical Bulletin 68. (1): 65-78.

Martinez, O.J. 1994. The dynamics of border interaction new approaches to border analysis. In Global Boundaries. World Boundaries Vol. 1. Ed.: SchofiLd, C.H., London, Routledge, 19-33.

Matznetter, W. 2004. The Vienna and Bratislava urban regions: Comparing urban development under (welfare) capitalism and (post-)communism . European Spatial Research and Policy 2. (1): 61-77.
MeYFroidt, A. 2016. Intégration transfrontalière et marché du logement: le cas de la région métropolitaine Vienne-Bratislava. Revue Géographique de l'Est 56. (3-4): 1-22.

Meyfroidt, A. 2017. Non-profit housing, a tool for metropolitan cohesion? The case of the Vienna-Bratislava region. Urban Research \& Practice 10. (4): 442-465.

Novotný, L. and Pregi, L. 2019. Región len pre mladých a vzdelaných? Selektívna migrácia vo funkčnom mestskom regióne Bratislava podla veku a vzdelania (A region only for young and educated people? Selective migration in the functional urban region of Bratislava by age and education). In Suburbanizácia. Ako sa mení zázemie Bratislavy? Eds.: Šveda, M. and ŠUšKA, P., Bratislava, Geografický ústav SAV, 134-159. Online-Plattform Österreichs (www.oesterreich.gv.at). OuŘEDNíčEK, M. 2002. Suburbanizace v kontextu urbanizačního procesu (Suburbanisation in the context of the urbanization process). In Suburbanizace a její sociální, ekonomické a ekologické důsledky. Eds.: Ouর̌EDNÍČEK, M. and Ś́коRA, L., Praha, Ústav pro ekopolitiku, 39-54.

Podolák, P. and Šveda, M. 2019. Suburbanizácia len pre Bratislavčanov? Komponenty populačného vývoja zázemia Bratislavy v kontexte suburbanizačných procesov (Suburbanisation only for residents of Bratislava? Components of the population development in the hinterland of Bratislava in the context of suburbanisation processes). In Suburbanizácia. Ako sa mení zázemie Bratislavy? Eds.: ŠvedA, M. and ŠUšKA, P., Bratislava, Geografický ústav SAV, 107-133.

Pт́́čeK, P. 2002. Suburbanizace v USA a Německu: zdroj inspirace i poučení (Suburbanisation in the USA and Germany: a source of inspiration and lessons). Suburbanizace a její sociální, ekonomické a ekologické důsledky. Eds.: Ouředníček, M. and SýKora, L., Praha, Ústav pro ekopolitiku, 55-80.

RowLAND, D.T. 1978. Evaluating the functions of internal migration in settlement systems. Canadian Studies in Population 5. 99-111.

Slaví́, V., Klobučník, M. and Kohútová, K. 2011. Vývoj rezidenčnej suburbanizácie $\mathrm{v}$ regióne Bratislava $\mathrm{v}$ rokoch 1990-2009 (Development of residential suburbanization in the region of Bratislava in 1990-2009). Forum Staticum Slovacum 43. (6): 169-175.

Stanilov, K. and Sýkora, L. 2014. Confronting Suburbanization: Urban Decentralization in Postsocialist Central and Eastern Europe. Chichester, Wiley Blackwell.

STATcube - Statistical Database (https://www.statistik.at).

Stillwell, J., Bell, M., Blake, M., Duke-Williams, O. and ReEs, P. 2000. Net migration and migration effectiveness: a comparison between Australia and the United Kingdom, 1976-96. Part 1: total migration patterns. Journal of the Australian Population Association 17. (1): $17-38$.

STRÜVER, A. 2005. Spheres of transnationalism within the European Union: on open doors, thresholds and 
drawbridges along the Dutch-German border. Journal of Ethnic and Migration Studies 31. (2): 323-343.

Šrrocha, B., BleHA, B., VAŇo, B. and BučEK, J. 2017. Perspektívy, riziká a výzzoy demografického vývoja najuäčších miest Slovenska (Perspectives, risks, and challenges of demographic development of the largest cities in Slovakia). Bratislava, INFOSTAT - Výskumné demografické centrum, Univerzita Komenského, Centrum spoločenských a psychologických vied.

ŠveDA, M. 2011a. Časové a priestorové aspekty bytovej výstavby v zázemí Bratislavy v kontexte suburbanizácie (Time and spatial aspects of housing construction on the outskirts of Bratislava in the context of suburbanization). Urbanismus a územní rozvoj 14. (3): 13-22.

ŠvedA, M. 2011b. Suburbanizácia v zázemí Bratislavy z hl'adiska analýzy zmien krajinnej pokrývky (Suburbanization in the hinterland of Bratislava in the view of analysis of land cover change). Geograficky časopis 63. (2): 155-173.

ŠvedA, M. 2016. Život v Bratislavskom suburbiu: Prípadová štúdia mesta Stupava (Living in the suburbia of Bratislava: Case study of Stupava). Sociológia / Slovak Sociological Review 48. (2): 139-171.

ŠveDA, M. and KRIžAN, F. 2011. Vývoj bytovej výstavby v slovenských mestách $\mathrm{v}$ ostatných rokoch $\mathrm{v}$ časových a priestorových súvislostiach (The dwelling construction in Slovak cities in the recent period in temporal and spatial context). Regionální studia 5. (2): 14-24.

Šveda, M. and PazúR, R. 2018. Priestorové formy rezidenčnej suburbanizácie zázemí Bratislavy (Spatial forms of residential suburbanization in the hinterland of Bratislava). Geografický časopis 70. (3): 231-258.
ŠveDA, M. and ŠUšKA, P. 2014. K príčinám a dôsledkom živelnej suburbanizácie v zázemí Bratislavy: Príklad obce Chorvátsky Grob (On the causes and consequences of unregulated suburbanization in the hinterland of Bratislava: Case study of Chorvátsky Grob). Geografický časopis 66. (3): 225-245.

ŠvedA, M. and Vigašová, D. 2010. Zmeny vo využití zeme v zázemí velkých slovenských miest (Land use changes in the hinterland of major Slovak cities). Geografie 115. (4): 413-439.

Šveda, M., Sládeková Madajová, M., Barlík, P. and BAGo, M. 2020a. Kam siaha Bratislava? Metropolitný región Bratislavy z pohl'adu lokalizačných údajov mobilnej siete (Where does Bratislava reach? The metropolitan region of Bratislava from the point of view of mobile network location data). In Suburbanizácia. Ako sa mení zázemie Bratislavy? Eds.: Šveda, M. and ŠUŠKA, P., Bratislava, Geografický ústav SAV, 51-82.

ŠvedA, M., Štefkovičová, P. and Tolmáči, L. 2020b. Do Rajky alebo do Kittsee? Rozdielne prostredie cezhraničnej suburbanizácie (To Rajka or to Kittsee? Different environments of cross-border suburbanisation). In Suburbanizácia. Ako sa menízázemie Bratislavy? Eds.: ŠveDA, M. and ŠušKa, P., Bratislava, Geografický ústav SAV, 221-240. 
